\title{
New V-shaped push-pull systems based on 4,5-di(hetero)aryl substituted pyrimidines: their synthesis and application to the detection of nitroaromatic explosives
}

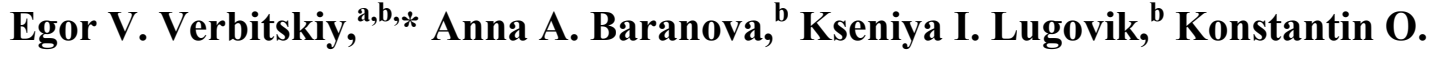 \\ Khokhlov, ${ }^{\text {b }}$ Ekaterina M. Cheprakova, ${ }^{\text {a Gennady L. Rusinov, }}{ }^{\text {a,b }}$ Oleg N. Chupakhin,, a,b \\ and Valery N. Charushin ${ }^{a, b}$ \\ ${ }^{a}$ Postovsky Institute of Organic Synthesis, Ural Branch of the Russian Academy of Sciences, \\ S. Kovalevskoy Str. 22, Ekaterinburg 620137, Russia \\ ${ }^{b}$ Ural Federal University, Mira Str. 19, Ekaterinburg 620002, Russia \\ E-mail: Verbitsky@ios.uran.ru
}

Dedicated to Professor Oleg G. Sinyashin on the occasion of his 60th anniversary

DOI: $\underline{\text { http://dx.doi.org/10.3998/ark.5550190.p009.470 }}$

\begin{abstract}
A number of $\mathrm{D}-\pi-\mathrm{A}-\pi-\mathrm{D}$ type dyes based on pyrimidines, bearing various electron-donating carbazole and triphenylamine fragments, have been studied as sensing fluorophores. Fluorescence studies demonstrated that the emission of all derivatives in acetonitrile is sensitive to the presence of a number of nitroaromatic benzenoids, including explosives such as 2,4dinitroanisole, picric acid, styphnic acid, 1,3,5-triethoxy-2,4,6-trinitrobenzene, 2,4-dinitrotoluene and 2,4,6-trinitrotoluene. Detection limits of fluorophores for the explosive compounds were in the range from $2 \mathrm{mM}$ to $29 \mu \mathrm{M}$. A selective fluorescence quenching response, including a sharp color change under UV, especially for the trinitrophenolics, makes these fluorophores promising fluorescence sensory materials for nitroaromatic explosives.
\end{abstract}

Keywords: Pyrimidine, carbazole, triphenylamine, nitroaromatic explosives, fluorescence quenching

\section{Introduction}

During the last decade, fast-reacting and reliable sensors for detection of highly explosive materials have acquired considerable interest, as effective tools to protect society from terrorism, and assist in environmental control. ${ }^{1-4}$ The most common explosives are nitroaromatic compounds. Current methods for the detection of nitroaromatic explosives are based on the use of dogs or sophisticated instruments, neither of which are always easily accessible. ${ }^{5-7}$ 
Fluorescence quenching techniques are more simple and sensitive tools. The design and synthesis of new organic fluorophores with a high emission efficiency for the detection of nitroaromatic explosives have attracted considerable attention. ${ }^{8-11}$ In this respect, electron rich conjugated polymers have proved to be excellent candidates for detection of such materials. ${ }^{6}$ When compared with conjugated polymers, however, small conjugated molecules have advantages due to their ease of synthesis and purification, in well-defined structures and better batch-to-batch reproducibility. ${ }^{7,12}$

Fluorescent organic molecules and polymers bearing $\pi$-conjugated triphenylamine or carbazole fragments have gained the attention of both experimental and theoretical chemists. Thanks to the presence of highly delocalized $\pi$-electronic systems, these molecules have found wide applications in organic light-emitting diodes (OLEDs), nonlinear optics, dye-sensitized solar cells and field-effect transistors (FETs). ${ }^{13-26}$ Furthermore, triphenylamine and carbazolebased compounds are used successfully as sensors for the detection of nitroaromatic explosives. $^{27-31}$

Oligothiophenes and their derivatives have also been employed successfully as sensing elements for detection of explosives. In particular, terthiophene derivatives have been immobilized in a monolayer on the surface of a glass plate, and the fluorescent films obtained used for the sensing of nitro-containing explosives both in the vapor phase and in aqueous media. $^{32-34}$

Pyrimidine is a very $\pi$-deficient heterocycle, and as a core it can be used as an electronwithdrawing component in push-pull structures. ${ }^{35,36}$ During the past decade, hundreds of pyrimidine-bearing chromophores have been designed. In particular, numerous aryl substituted pyrimidines have been studied as fluorescent dyes. ${ }^{35-38}$ Moreover, it should be noted that arylvinyl pyrimidines are now considered as well established structures of two-photon absorption dyes. $^{39-41}$ Also some pyrimidines exhibit second order nonlinear optical properties. ${ }^{42,43}$ In continuation of our previous studies on (hetero)aryl substituted bithiophenes and their analogues, as photosensitizers for dye-sensitized solar cells, ${ }^{22,23,44}$ and taking into account the results reported by other groups on the use of pyrimidine-triphenylamine and pyrimidine-carbazole dyads in optical materials, ${ }^{35,36}$ we have focused our attention on donor- $\pi$-acceptor organic dyes bearing the pyrimidine fragment, as chemosensors for nitroaromatic explosives. In this communication we report the synthesis of pyrimidine-based $\mathrm{V}$-shaped new organic fluorophores with yellow-green emission, their photophysical properties and sensitivity towards nitroaromatics.

\section{Results and Discussion}

\section{Synthesis}

It has already been shown that 5-bromo-2-(hetero)arylpyrimidines react with a variety of (hetero)aryl-substituted boronic acids under Pd-catalyzed microwave-assisted conditions. ${ }^{45,46}$ 
4,5-Bis-(5-bromothien-2-yl)pyrimidine (4) was used as a synthetic intermediate in the preparation of $\mathrm{V}$-shaped push-pull systems after the model of 4,5-di(hetero)aryl substituted pyrimidines 6a-c. Compound 4 was obtained by conversion of the readily available 5-bromo-4(thien-2-yl)pyrimidine (2) into 4,5-di(thien-2-yl)pyrimidine (3) in $\mathrm{THF} / \mathrm{H}_{2} \mathrm{O}$ (3:4), which is similar to the microwave-assisted Suzuki cross-coupling reaction, followed by bromination of 3 to 4 (Scheme 1). ${ }^{47}$ The target chromophores 6a-c were synthesized in high yields through the reactions shown in Scheme 2. Pyrimidine 4 was coupled with the corresponding pinacol esters of 4-(diphenylamino)phenylboronic (5a), 9-ethyl-9H-carbazole-3-boronic (5b) and 9H-carbazole-9(4-phenyl)boronic acids (5c) under microwave irradiation in 1,4-dioxane/ $\mathrm{H}_{2} \mathrm{O}$, in the presence of $\mathrm{K}_{2} \mathrm{CO}_{3}$ and $\mathrm{Pd}\left(\mathrm{PPh}_{3}\right)_{4}$ as catalyst. These reactions afforded the corresponding $\mathrm{D}-\pi-\mathrm{A}-\pi$-D dyes 6a-c in 64-75\% yields in reaction times not exceeding 20 min (Scheme 2).

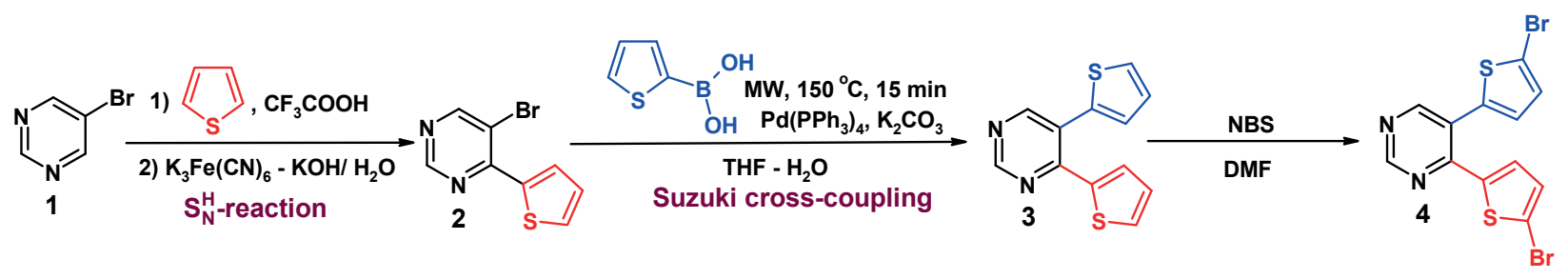

Scheme 1. Synthesis of 4,5-bis-(5-bromothien-2-yl)pyrimidine (4).

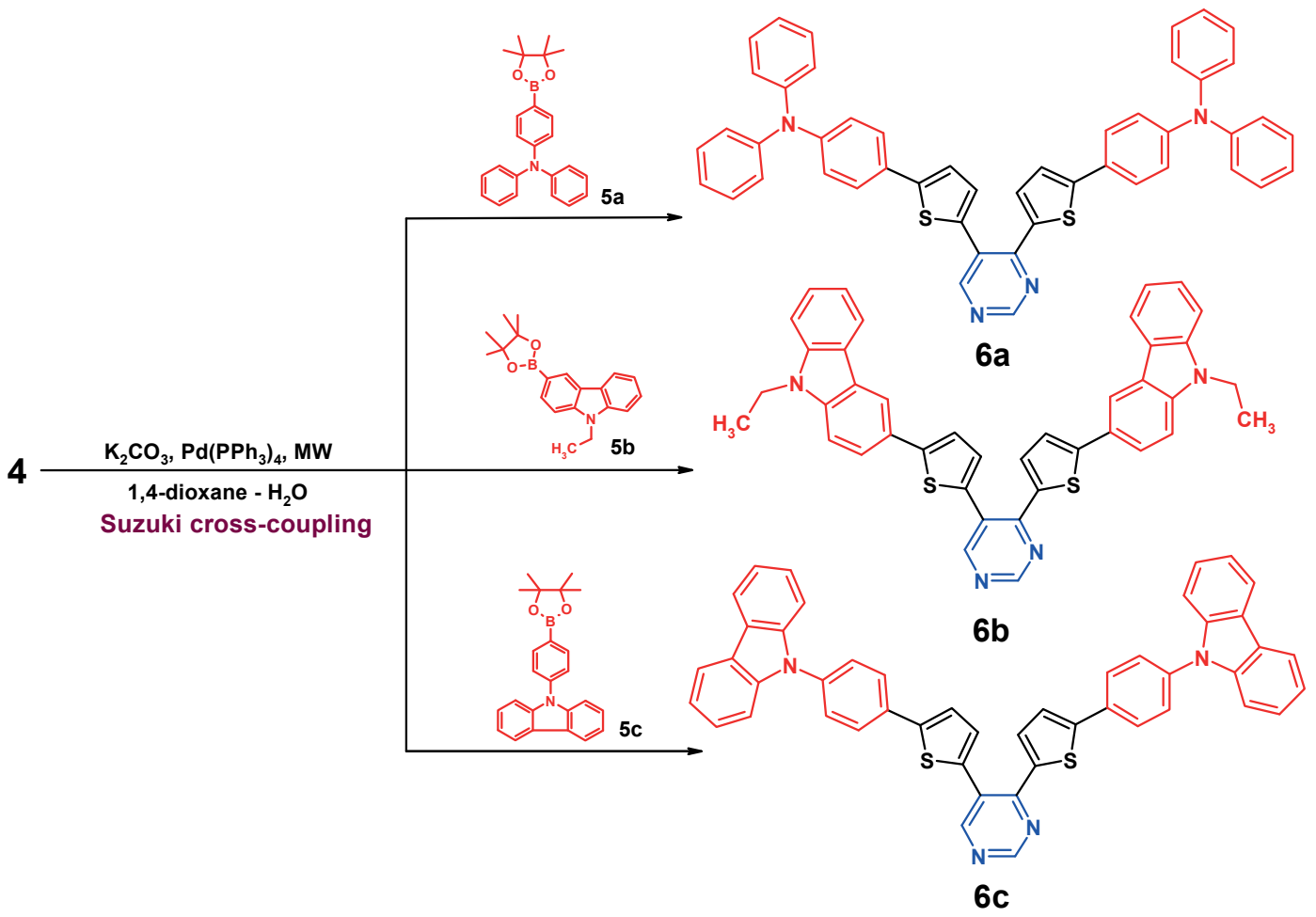

Scheme 2. Molecular structures and synthetic route to the donor- $\pi$-acceptor organic dyes on a pyrimidine scaffold. 


\section{Absorption and emission properties}

A characteristic feature of this class of compound is that their absorption and emission wavelengths can be easily adjusted by suitable design of their structures. To evaluate the effect of triphenylamine and carbazole moieties on photophysical properties, the fluorescence excitation and emission spectra of 6a-c were recorded. The spectra are shown in Figure 1 and the main optical properties are presented in Table 1.

The pyrimidine fluorophores 6a-c show broad absorption maxima in the region of 340-405 $\mathrm{nm}$ ( $\varepsilon$ 17700-23700 $\mathrm{M}^{-1} \cdot \mathrm{cm}^{-1}$ ), which can be attributed to intramolecular charge-transfer excitation from the carbazole or triphenylamine moiety to the pyrimidine ring (Table 1, Fig. 1a). The second and third absorption maxima were seen at 294-361 and 237-299 nm, respectively. The effects of molecular structure on the absorption properties are seen in the hypsochromic shift of the long-wavelength absorption bands, of approximately $63 \mathrm{~nm}$ from the triphenylamine derivative 6a to the 9-phenyl-9H-carbazole compound 6c (Table 1). Since the ionization potential of triphenylamine is lower than that of carbazole, it is reasonable to suppose that enhancement of the electron-donating ability of the D-fragment of the dye is responsible for the hypsochromic shift. Such dependence is inherent in the absorption bands which are due to intramolecular charge transfer. ${ }^{48}$

Effective channel deactivation of electronic excitation energy for dyes 6a-c is the source of the fluorescence (Table 1, Figure 1b). The excitation spectra coincided with the absorption bands (Table 1). The influence of the structure of dyes 6a-c on the fluorescence spectra is similar to that found for the absorption spectra.

The Stokes shift is an important parameter for a fluorophore, since it provides directly a measure of the energy gap between the ground and the first excited state of the fluorophore. ${ }^{34}$ For the fluorophores under consideration, their Stokes shifts to vary from $6497(\mathbf{6 b})$ to $9881 \mathrm{~cm}^{-1}$ (6c) (see Table 1). High values of the Stokes shifts may be due to a change in the dipole moments of dyes in the excited state, resulting from charge transfer from donor to acceptor, which is accompanied by a compensatory relaxation of solvent molecules. ${ }^{23}$

(a)

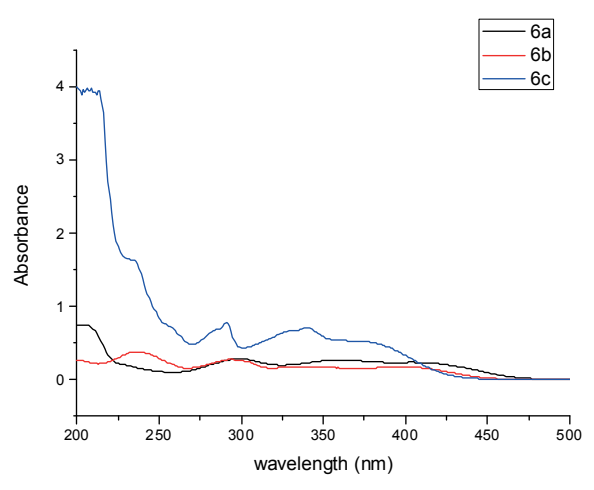

(b)

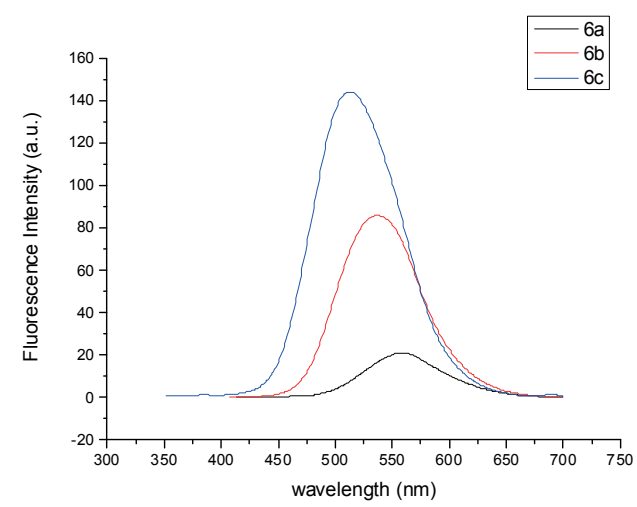

Figure 1. Absorption and emission spectra of fluorophores 6a-c. (a) Absorption spectra of 6a-c in $\mathrm{CH}_{3} \mathrm{CN}$. (b) Emission spectra of 6a-c in $\mathrm{CH}_{3} \mathrm{CN}$. 
Table 1. Photophysical data for fluorophores 6a-c in acetonitrile

\begin{tabular}{|c|c|c|c|c|c|}
\hline \multirow[b]{2}{*}{ Fluorophores } & \multirow{2}{*}{$\begin{array}{l}\text { Absorption } \\
\lambda_{\max }(\mathrm{nm}) / \varepsilon \\
\left(10^{3} / \mathrm{M}^{-1}\right. \\
\left.\mathrm{cm}^{-1}\right)\end{array}$} & \multicolumn{2}{|c|}{ Fluorescence } & \multirow[b]{2}{*}{$\begin{array}{l}\text { Quantum } \\
\text { yield }(\Phi)\end{array}$} & \multirow[b]{2}{*}{$\begin{array}{l}\text { Stokes shift } \\
\Delta v_{\text {st }} / \mathrm{cm}^{-1}\end{array}$} \\
\hline & & $\begin{array}{l}\text { Excitation } \\
\lambda_{\max }(\mathrm{nm})\end{array}$ & $\begin{array}{l}\text { Emission } \\
\lambda_{\max }(\mathrm{nm}) \\
\end{array}$ & & \\
\hline \multirow{3}{*}{$6 \mathbf{a}$} & $403 / 23.70$ & & & & \\
\hline & $361 / 27.20$ & 403 & 557 & 0.01 & 6861 \\
\hline & $299 / 28.90$ & & & & \\
\hline \multirow{3}{*}{$6 \mathbf{b}$} & $397 / 17.70$ & & & & \\
\hline & $294 / 27.70$ & 397 & 535 & 0.05 & 6497 \\
\hline & $237 / 38.40$ & & & & \\
\hline \multirow{4}{*}{$6 c$} & $370 / 53.00$ & & & & \\
\hline & $340 / 71.00$ & 340 & 512 & 0.07 & 9881 \\
\hline & $291 / 77.30$ & 340 & 312 & 0.01 & 9881 \\
\hline & $234 / 163.90$ & & & & \\
\hline
\end{tabular}

\section{Fluorescence quenching studies in acetonitrile solution}

To evaluate the utility of the $\mathrm{D}-\pi-\mathrm{A}-\boldsymbol{\pi}-\mathrm{D}$ type dyes $\mathbf{6 a - c}$ based on the pyrimidine scaffold for the detection of nitroaromatic explosives, the corresponding fluorescence measurements of the fluorophores 6a-c were carried out in acetonitrile solutions containing measured quantities of the compounds shown in Figure 2, which serve as quenchers of the fluorescence.

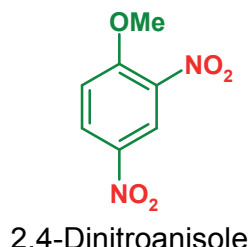

2,4-Dinitroanisole

(DNAN)

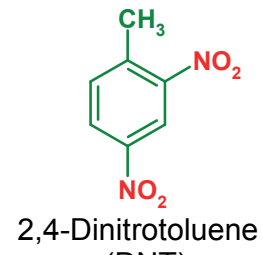

(DNT)

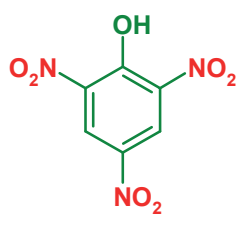

Picric acid (PA)

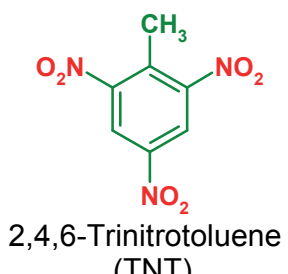<smiles>O=[N+]([O-])c1cc([N+](=O)[O-])c(O)c([N+](=O)[O-])c1O</smiles>

Styphnic acid (SA)<smiles>CCOc1c([N+](=O)[O-])c(OCC)c([N+](=O)[O-])c(OCC)c1[N+](=O)[O-]</smiles>

1,3,5-Triethoxy-2,4,6-trinitrobenzene (TETNB)

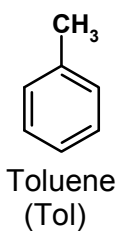

Figure 2. Structures of used quenchers (green) and interferents (black).

Figures 3, S1 and S2 (see Supplementary Material) show the fluorescence emission spectra of 6a-c in the presence of different concentrations of the analytes with $385 \mathrm{~nm}$ as an excitation wavelength. All nitroaromatics act as fluorescence quenchers for compounds 6a-c. In this series, 
the most effective quenchers are picric and styphnic acids, while DNT and TNT are the least

(a)

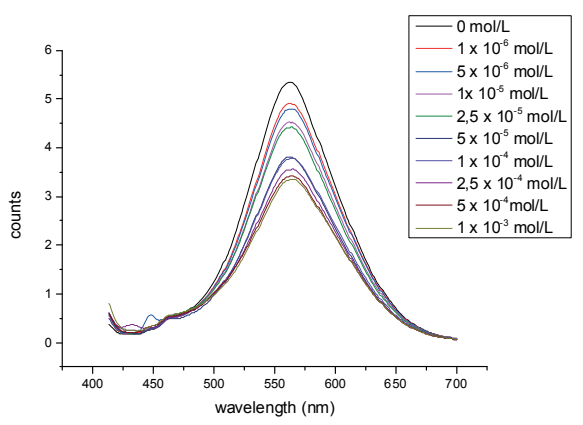

(c)

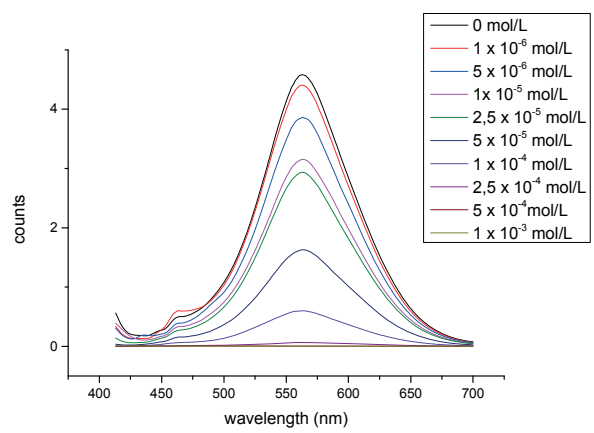

(e)

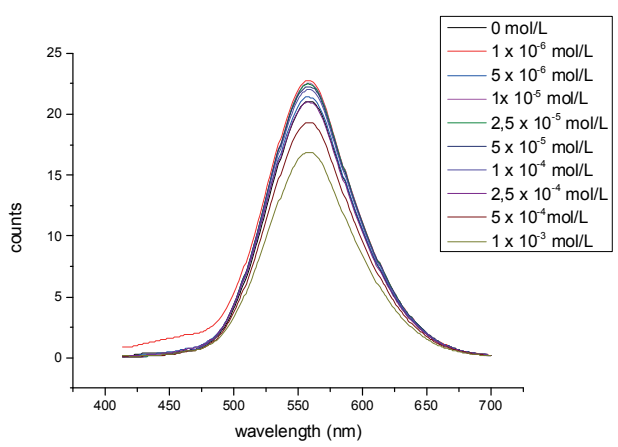

$(\mathrm{g})$

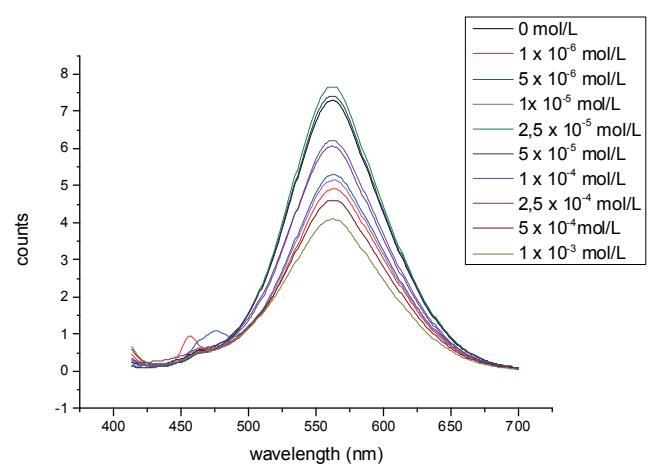

(b)

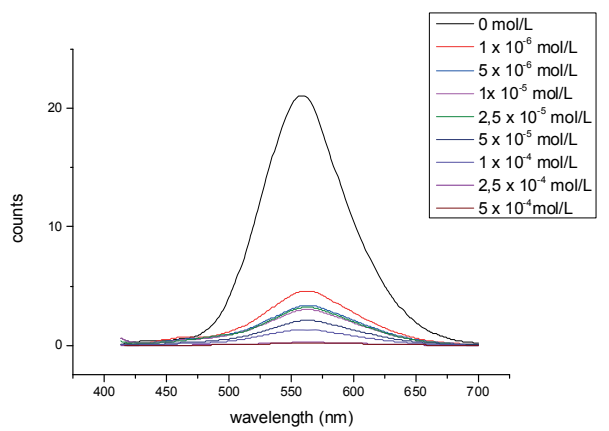

(d)

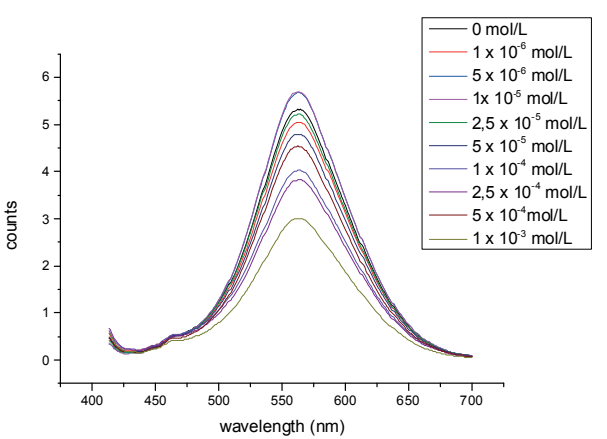

(f)

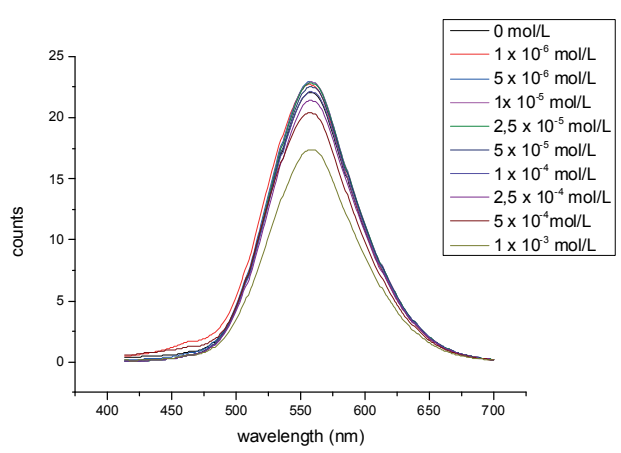

(h)

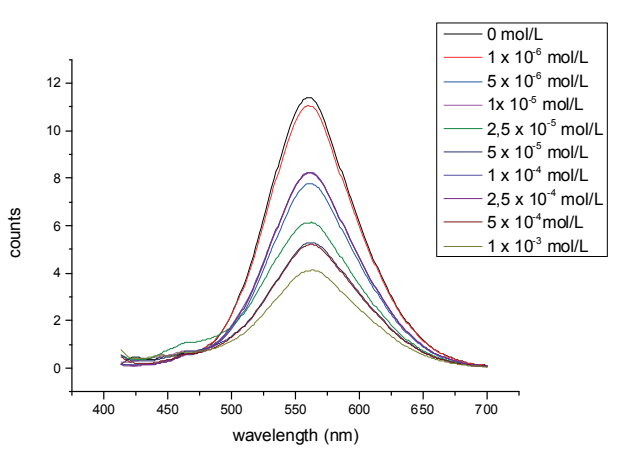

Figure 3. Fluorescence quenching studies for $6 \mathbf{a}\left(1.0 \times 10^{-5} \mathrm{~mol} / \mathrm{L}\right)$ recorded in the presence of various amounts of DNAN (a), PA (b), SA (c), TETNB (d), DNT (e), TNT (f), NB (g) and Tol (h), for which $385 \mathrm{~nm}$ was taken as the excitation wavelength. 
effective (Figure 4). It can be seen that fluorophore 6a exhibits a fast and sensitive response to PA and SA, and nearly $35-85 \%$ and $5-45 \%$ of the original emission values are quenched by this fluorophore when their concentrations reach $1.0 \times 10^{-6} \mathrm{~mol} / \mathrm{L}$.

The most impressive visual changes of color for fluorophores 6a-c solutions with additives of different quenchers are shown in Figures 4, S3 and S4.

(a)
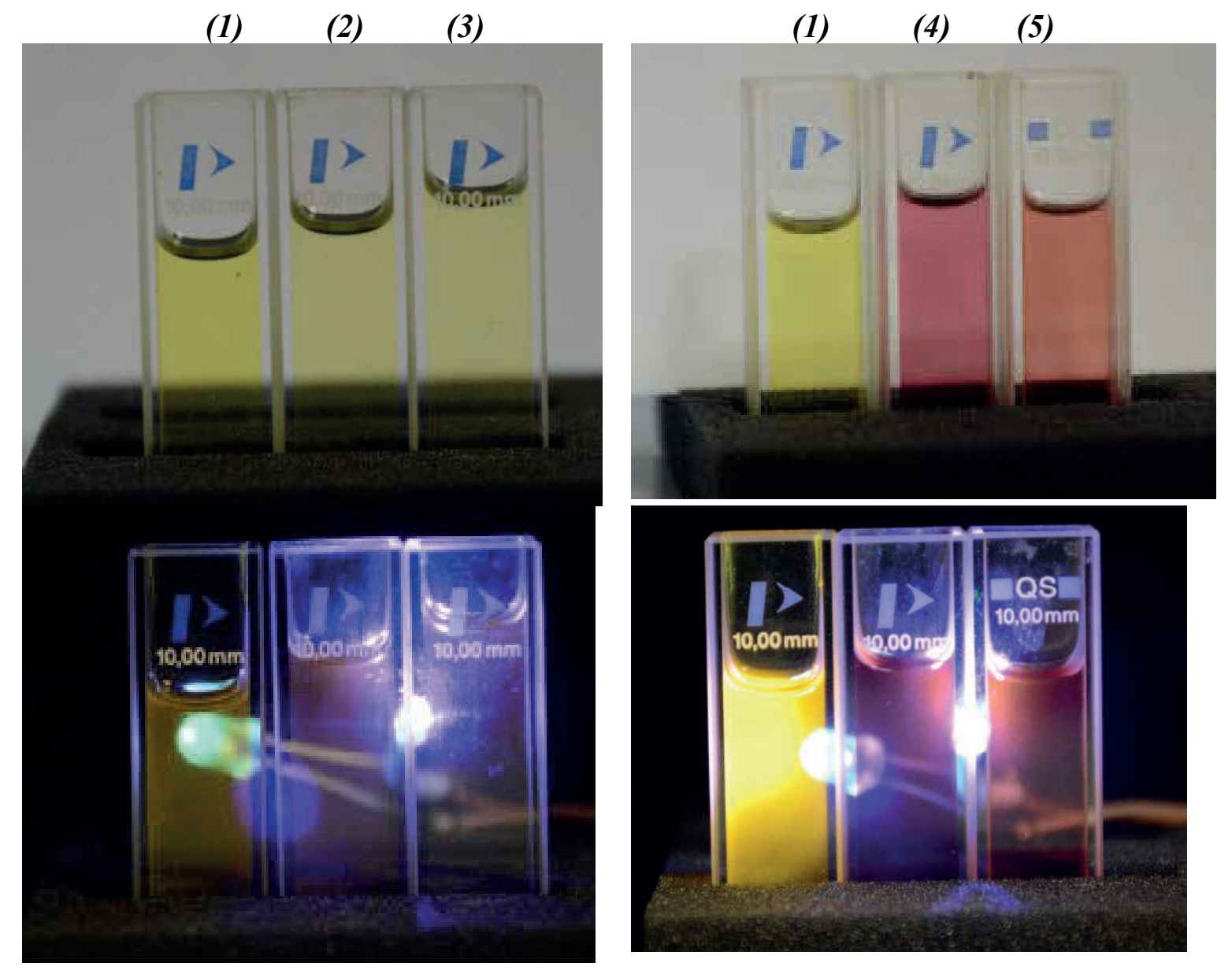

Figure 4. Solution photographs of compound $6 \mathbf{a}\left(c=1.0 \times 10^{-5} \mathrm{M}\right)$ in acetonitrile $(1)$, solution $6 \mathbf{a}$ in the presence of TETNB $\left(c=1.0 \times 10^{-5} \mathrm{M}\right)$ in acetonitrile $(b)$, solution $6 \mathbf{a}$ in the presence of $\operatorname{DNAN}\left(c=1.0 \times 10^{-5} \mathrm{M}\right)$ in acetonitrile $(3)$, solution $6 \mathbf{a}$ in the presence of PA $\left(c=1.0 \times 10^{-5} \mathrm{M}\right)$ in acetonitrile (4), solution $6 \mathbf{a}$ in the presence of SA $\left(c=1.0 \times 10^{-5} \mathrm{M}\right)$ in acetonitrile (5): before irradiation (a - no emission) and during irradiation $\left(\mathrm{b}-\right.$ emission, $\lambda_{\mathrm{ex}}=375 \mathrm{~nm}$ ) at room temperature.

The quenching efficiency was calculated by using the formula $\left(I_{0}-I\right) / I_{0} \times 100 \%$, where $I_{0}$ and $I$ are the fluorescence intensities of fluorophores $6 \mathbf{a}, \mathbf{6 b}$ or $\mathbf{6 c}$ before and after addition of the analyte, respectively. Figure 5 shows the quenching efficiency of nitroaromatics and related compounds. 
(a)

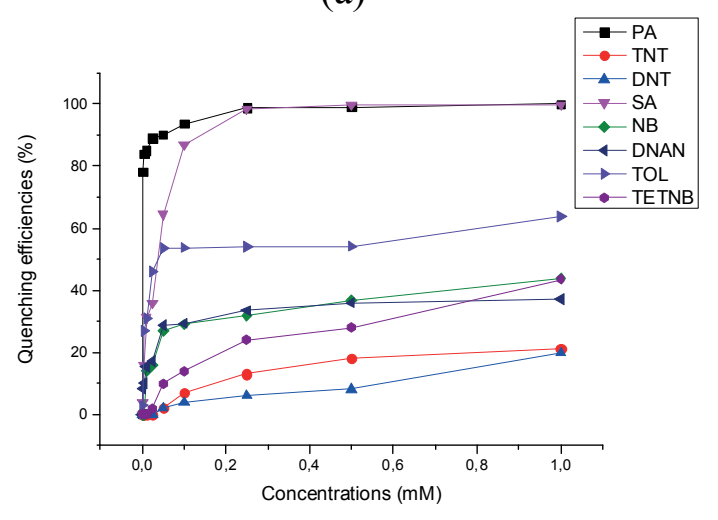

(b)

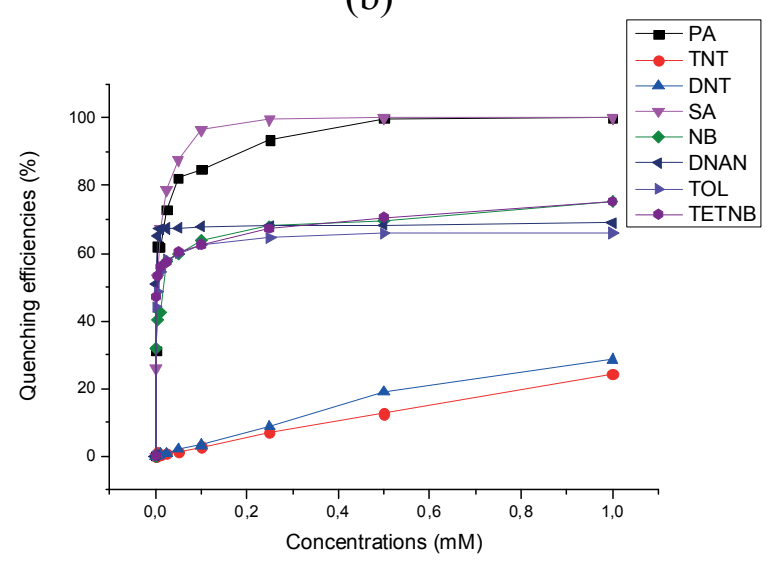

(c)

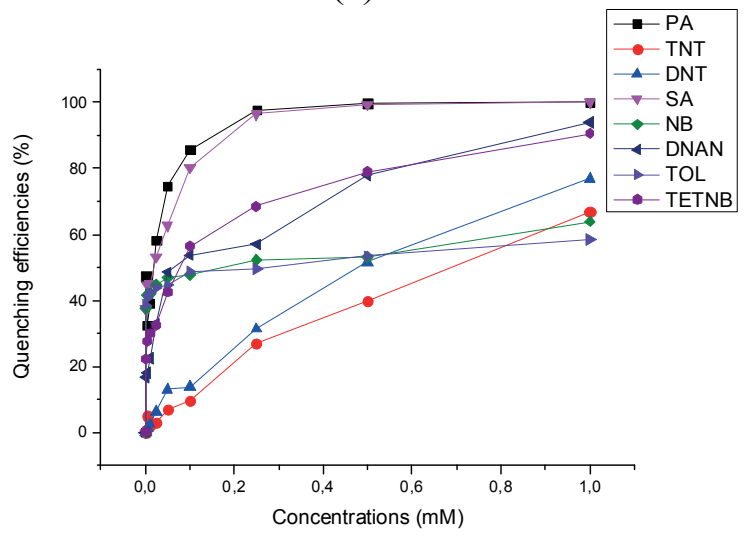

Figure 5. The plot of the quenching efficiencies of DNAN, PA, SA, TETNB, DNT, TNT, NB and Tol to fluorophores $\mathbf{6 a}(\mathrm{a}), \mathbf{6 b}(\mathrm{b})$ and $\mathbf{6 c}(\mathrm{c})$ at $\mathrm{mM}$ level.

Table 2. Quenching constants $K_{\mathrm{SV}}$ and detection limits of DNAN, PA, SA, TETNB, DNT, TNT, $\mathrm{NB}$ and Tol towards fluorophores $\mathbf{6 a - c}$ in $\mathrm{CH}_{3} \mathrm{CN}$

\begin{tabular}{|c|c|c|c|c|c|c|c|c|}
\hline \multirow{2}{*}{$\begin{array}{l}\text { Fluoro- } \\
\text { phores }\end{array}$} & \multicolumn{8}{|c|}{$K \mathrm{sv}, \mathrm{M}^{-1} / \mathrm{DL}, \mathrm{mol} \times \mathrm{L}^{-1}$} \\
\hline & DNAN & PA & SA & TETNB & DNT & TNT & NB & TOL \\
\hline \multirow{2}{*}{$6 \mathbf{6 a}$} & $590 /$ & $10667 /$ & 9000/ & $769 /$ & $246 /$ & $268 /$ & $781 /$ & $1757 /$ \\
\hline & $2.04 \times 10^{-3}$ & $6.86 \times 10^{-4}$ & $4.94 \times 10^{-5}$ & $1.54 \times 10^{-3}$ & $5.35 \times 10^{-4}$ & $5.92 \times 10^{-4}$ & $3.77 \times 10^{-3}$ & $4.54 \times 10^{-4}$ \\
\hline \multirow{2}{*}{$6 \mathbf{b}$} & $2162 /$ & $10500 /$ & $7125 /$ & $3049 /$ & $400 /$ & $324 /$ & $3609 /$ & $1720 /$ \\
\hline & $1.96 \times 10^{-4}$ & $5.55 \times 10^{-5}$ & $7.15 \times 10^{-4}$ & $1.22 \times 10^{-4}$ & $1.35 \times 10^{-4}$ & $1.55 \times 10^{-4}$ & $1.56 \times 10^{-4}$ & $5.07 \times 10^{-3}$ \\
\hline \multirow{2}{*}{$6 c$} & $15565 /$ & $26627 /$ & $18250 /$ & $9636 /$ & $3327 /$ & $2026 /$ & $1779 /$ & $1404 /$ \\
\hline & $2.88 \times 10^{-5}$ & $4.00 \times 10^{-5}$ & $3.70 \times 10^{-5}$ & $4.65 \times 10^{-5}$ & $2.86 \times 10^{-5}$ & $3.04 \times 10^{-5}$ & $1.26 \times 10^{-4}$ & $1.05 \times 10^{-4}$ \\
\hline
\end{tabular}

We have tried to suggest quenching mechanism for example of interaction DNAN with a different fluorophores 6a-c. The linear response of the Stern-Volmer plot (in a range of concentrations from 0 to $5 \times 10^{-5} \mathrm{M}$ ) and the lifetime measurements upon addition of DNAN 
suggest the high role of static type of quenching process (Figures S5-10 and Table S1 in Supplementary Material). In other words, formation of a complex between DNAN and 6a-c may be the origin of the quenching, a result similar to those reported by others in the studies of sensing behaviors of conjugated oligothiophenes. ${ }^{49}$

\section{Conclusions}

In summary, new V-shaped push-pull systems based on 4,5-di(hetero)aryl substituted pyrimidines have been studied as sensing fluorophores. These dyes show remarkable sensitivity towards the presence of various nitroaromatic explosives. Selective fluorescence quenching response, including a sharp color change under UV lamp, especially for PA and SA, makes these fluorophores to be promising fluorescence sensory materials for nitro-containing explosives with a detection limit of $10^{-5} \mathrm{~mol} / \mathrm{L}$. The present study may be a significant step towards the development of pyrimidine dyes with thiophene linkers, as a new series of sensing fluorophores.

\section{Experimental Section}

General. All reagents and solvents were obtained from commercial sources and dried by using standard procedures before use. Nitro-containing explosives, including 2,4-dinitroanisole (DNAN), picric acid (PA), styphnic acid (SA), 1,3,5-triethoxy-2,4,6-trinitrobenzene (TETNB), 2,4-dinitrotoluene (DNT), 2,4,6-trinitrotoluene (TNT) were of analytical grade and used directly without further purification. (Caution: Most nitro-containing compounds used in the present study are high explosives and should be handled only in small quantities.) 4,5-Bis[5bromo(thien-2-yl)]pyrimidine (4) was prepared according to the earlier reported method. ${ }^{47}$ The solvents $\left(1,4\right.$-dioxane and $\left.\mathrm{H}_{2} \mathrm{O}\right)$ for the microwave-assisted Suzuki cross-coupling reaction were degassed by bubbling argon for $1 \mathrm{~h}$.

${ }^{1} \mathrm{H}$ and ${ }^{13} \mathrm{C}$ NMR spectra were recorded on a AVANCE-500 instruments using $\mathrm{Me}_{4} \mathrm{Si}$ as an internal standard. Elemental analysis was carried on a Eurovector EA 3000 automated analyzer. Melting points were determined on Boetius combined heating stages.

Flash column chromatography was carried out using Alfa Aesar silica gel 0.040-0.063 mm (230400 mesh), eluting with ethyl acetate-hexane. The progress of reactions and the purity of compounds were checked by TLC on Sorbfil plates (Russia), in which the spots were visualized with UV light ( $\lambda 254$ or $365 \mathrm{~nm}$ ).

Microwave heating were carried out in a Discover unimodal microwave system (CEM, USA) with a working frequency of $2.45 \mathrm{GHz}$ and the power of microwave radiation ranged from 0 to $300 \mathrm{~W}$. The reactions were carried out in $10 \mathrm{~mL}$ reaction tubes with hermetic Teflon seal. The temperature of the reaction was monitored using an inserted IR sensor by the external surface of the reaction vessel.

UV-vis spectra were recorded for a $1 \times 10^{-5} \mathrm{M}$ acetonitrile solution with Shimadzu UV-2401PC spectrophotometer. Fluorescence spectra measurements were performed on a Hitachi F-7000 
fluorescence spectrophotometer at room temperature. Quantum yields $(\Phi)$ were estimated with $1 \mathrm{~N} \mathrm{H}_{2} \mathrm{SO}_{4}$ solution of quinine bisulfate $(\Phi=0.55)$ as a reference. ${ }^{50}$

The fluorescence quenching studies were conducted in acetonitrile. For each analyte, the typical test procedure was as follows: a $2.5 \mathrm{~mL}$ of the acetonitrile solution of one of the fluorophores $\left(1.0 \times 10^{-5} \mathrm{~mol} / \mathrm{L}\right)$ was drawn and placed in a quartz cell with a standard size, and then the measurement conducted. In the absence of analyte, the fluorescence spectrum of pure fluorophore was first recorded. Subsequently, different amounts of analyte were respectively added into the above cell. Each time after fully mixing the analyte with the fluophore, the fluorescence spectrum was collected at once. The plots of the $I_{0} / I$ values of the quenching systems as functions of quencher concentrations $([Q])$ were well described by the Stern-Volmer equation, $I_{0} / I=1+K_{\mathrm{sv}}[Q]$, where $I_{0}$ and $I$ are the fluorescence intensities in the absence and presence of an analyte of a system.

General procedure for the synthesis of 4,5-di(hetero)aryl pyrimidine derivatives (6a-c). A solution of $\mathrm{K}_{2} \mathrm{CO}_{3}(173 \mathrm{mg}, 1.25 \mathrm{mmol})$ in $3 \mathrm{~mL} \mathrm{H} \mathrm{H}_{2} \mathrm{O}$ was added to a mixture of 4,5-bis[5bromo(thien-2-yl)]pyrimidine (4) (121 $\mathrm{mg}, 0.5 \mathrm{mmol})$, 4-(diphenylamino)phenylboronic (5a) [9-ethyl-9H-carbazole-3-boronic (5b) or 9H-carbazole-9-(4-phenyl)boronic acids (5c)] acid (1.25 $\mathrm{mmol})$ and $\mathrm{Pd}\left(\mathrm{PPh}_{3}\right)_{4}(58 \mathrm{mg}, 10 \mathrm{~mol} \%)$ in 1,4-dioxane $(4 \mathrm{~mL})$. The resulting mixture was irradiated in a microwave apparatus at $165{ }^{\circ} \mathrm{C}(200 \mathrm{~W})$ for $20 \mathrm{~min}$. After that solvent was distilled off in vacuo, and the residue was purified by flash column chromatography (hexane/ethyl acetate, 1:3) to afford the desired cross-coupling products (6a, $\mathbf{6 b}$ and $\mathbf{6 c}$ ).

4,5-Bis $\{5$-[4-(diphenylamino)phenyl](thien-2-yl)\}pyrimidine (6a). Yield $245 \mathrm{mg}$, 67\%, dark yellow powder, mp $113-115^{\circ} \mathrm{C} . \delta_{\mathrm{H}}\left(500 \mathrm{MHz}, \mathrm{DMSO}-d_{6}\right) 6.94(\mathrm{~d}, 2 \mathrm{H}, J 8.7 \mathrm{~Hz}), 6.99(\mathrm{~d}, 2 \mathrm{H}, J$ $8.7 \mathrm{~Hz}), 7.03(\mathrm{~d}, 1 \mathrm{H}, J 4.1 \mathrm{~Hz}), 7.04-7.12(\mathrm{~m}, 12 \mathrm{H}), 7.30(\mathrm{~d}, 1 \mathrm{H}, J 3.7 \mathrm{~Hz}), 7.31-7.35(\mathrm{~m}, 9 \mathrm{H})$, $7.53(\mathrm{~d}, 1 \mathrm{H}, J 3.7 \mathrm{~Hz}), 7.57$ (d, 2H, J 8.7 Hz), $7.60(\mathrm{~d}, 2 \mathrm{H}, J 8.7 \mathrm{~Hz}), 8.74(\mathrm{~s}, 1 \mathrm{H}, \mathrm{H}-6), 9.11(1 \mathrm{H}$, s, H-2). $\delta_{\mathrm{C}}\left(126 \mathrm{MHz}, \mathrm{DMSO}-d_{6}\right) 122.22,122.94,123.23,123.48,123.75,124.06,124.31$, 124.64, 126.36, 126.59, 126.79, 126.95, 129.61, 129.66, 130.23, 132.01, 134.03, 138.67, 145.65, 146.56, 146.74, 147.16, 147.72, 148.36, 156.05, 157.70, 159.03. Calcd. for $\mathrm{C}_{48} \mathrm{H}_{34} \mathrm{~N}_{4} \mathrm{~S}_{2}$ (730.96): C 78.87, H 4.69, N 7.66. Found C 78.75, H 4.55, N 7.51\%.

4,5-Bis $\{5$-[9-ethyl-9H-carbazole](thien-2-yl)\}pyrimidine (6b). Yield $202 \mathrm{mg}$, 64\%, yellow powder, mp $120-122{ }^{\circ} \mathrm{C} . \delta_{\mathrm{H}}\left(500 \mathrm{MHz}, \mathrm{DMSO}-d_{6}\right) 1.31\left(\mathrm{dt}, 6 \mathrm{H}, J 14.1,7.1 \mathrm{~Hz}, \mathrm{CH}_{3}\right), 4.44(\mathrm{dq}$, $\left.4 \mathrm{H}, J 14.4,7.0 \mathrm{~Hz}, \mathrm{NCH}_{2}\right), 7.15-7.26(\mathrm{~m}, 3 \mathrm{H}), 7.36(\mathrm{~d}, 1 \mathrm{H}, J 3.6 \mathrm{~Hz}), 7.43-7.52(\mathrm{~m}, 3 \mathrm{H}), 7.57-$ $7.68(\mathrm{~m}, 4 \mathrm{H}), 7.70(\mathrm{~d}, 1 \mathrm{H}, J 3.6 \mathrm{~Hz}), 7.77(\mathrm{dd}, 1 \mathrm{H}, J 8.6,1.5 \mathrm{~Hz}), 7.82(\mathrm{dd}, 1 \mathrm{H}, J 8.6,1.5 \mathrm{~Hz})$, $8.21(\mathrm{~d}, 1 \mathrm{H}, J 7.7 \mathrm{~Hz}), 8.27(\mathrm{~d}, 1 \mathrm{H}, J 7.7 \mathrm{~Hz}), 8.53(\mathrm{~d}, 1 \mathrm{H}, J 1.2 \mathrm{~Hz}), 8.57$ (d, $1 \mathrm{H}, J 1.2 \mathrm{~Hz}), 8.80$ (s, $1 \mathrm{H}, \mathrm{H}-6), 9.16(1 \mathrm{H}, \mathrm{s}, \mathrm{H}-2) . \delta_{\mathrm{C}}\left(126 \mathrm{MHz}\right.$, DMSO- $\left.d_{6}\right) 14.13,14.14,25.39,37.54,109.80$, 109.84, 110.17, 110.20, 117.92, 118.24, 119.53, 119.63, 121.17, 121.23, 122.49, 122.54, 123.16, 123.21, 123.51, 123.80, 124.18, 124.21, 124.46, 124.72, 126.65, 126.72, 130.64, 132.60, 134.06, 138.76, 139.77, 140.08, 140.53, 147.84, 150.70, 156.72, 158.14, 159.49. Calcd. for $\mathrm{C}_{40} \mathrm{H}_{30} \mathrm{~N}_{4} \mathrm{~S}_{2}$ (630.84): C 76.16, H 4.79, N 8.88. Found C 76.14, H 4.87, N 8.80\%. 
4,5-Bis $\{$ 5-[9H-carbazole-9-(4-phenyl)](thien-2-yl)\}pyrimidine (6c). Yield $273 \mathrm{mg}, 75 \%$, yellow powder, mp $265-268{ }^{\circ} \mathrm{C} . \delta_{\mathrm{H}}\left(500 \mathrm{MHz} \mathrm{CDCl}_{3}\right) 7.23(\mathrm{~d}, 1 \mathrm{H}, J 3.7 \mathrm{~Hz}), 7.26-7.34(\mathrm{~m}, 6 \mathrm{H})$, 7.38-7.49 (m, 8H), $7.50(\mathrm{~d}, 1 \mathrm{H}, J 3.7 \mathrm{~Hz}), 7.57-7.68(\mathrm{~m}, 4 \mathrm{H}), 7.83-7.93(\mathrm{~m}, 4 \mathrm{H}), 8.15(\mathrm{t}, 4 \mathrm{H}, J$ $7.7 \mathrm{~Hz}), 8.73$ (s, 1H, H-6), $9.17(1 \mathrm{H}, \mathrm{s}, \mathrm{H}-2) . \delta_{\mathrm{C}}\left(126 \mathrm{MHz}, \mathrm{CDCl}_{3}\right)$ 109.70, 109.74, 120.19, $120.37,120.40,123.53,124.19,126.04,127.22,127.38,127.43,127.55,129.70,132.27,132.56$, 132.65, 136.04, 137.50, 137.84, 140.55, 140.58, 140.64, 145.91, 148.39, 157.15, 157.99, 159.20. Calcd. for $\mathrm{C}_{48} \mathrm{H}_{30} \mathrm{~N}_{4} \mathrm{~S}_{2}$ (726.93): C 79.31, H 4.16, N 7.71. Found C 79.26, H 3.99, N 7.66\%.

\section{Acknowledgements}

The research was financially supported by the Russian Science Foundation (Project No. 16-1310435) and by Act 211 Government of the Russian Federation, contract № 02.A03.21.0006.

\section{References}

1. Yinon, J. Anal. Chem. 2003, 75, 98A. http://dx.doi.org/10.1021/ac020428b

2. Jiménez, A. M.; Navas, M. J. J. Hazard. Mater. 2004, 106A, 1. http://dx.doi.org/10.1016/j.jhazmat.2003.07.005

3. Toal, S. J.; Trogler, W. C. J. Mater. Chem. 2006, 16, 2871. http://dx.doi.org/10.1039/B517953J

4. Suman, S. J. Hazard. Mater. 2007, 144, 15. http://dx.doi.org/10.1016/j.jhazmat.2007.02.018

5. Moore, D. S. Rev. Sci. Instrum. 2004, 75, 2499. http://dx.doi.org/10.1063/1.1771493

6. Thomas, S. W.; Joly, G. D.; Swager, T. M. Chem. Rev. 2007, 107, 1339. http://dx.doi.org/10.1021/cr0501339

7. Zyryanov, G. V.; Kopchuk, D. S.; Kovalev, I. S.; Nosova, E. V.; Rusinov, V. L.; Chupakhin, O. N. Russ. Chem. Rev. 2014, 83, 783 and references cited therein. http://dx.doi.org/10.1070/RC2014v083n09ABEH004467

8. Peng, Y.; Zhang, A.-J.; Dong, M.; Wang, Y.-W. Chem. Commun. 2011, 47, 4505. http://dx.doi.org/10.1039/c1cc10400d

9. Bhalla, V.; Gupta, A.; Kumar, M. Org. Lett. 2012, 14, 3112. http://dx.doi.org/10.1021/o1301202v

10. Roy, B.; Bar, A. K.; Gole, B.; Mukherjee, P. S. J. Org. Chem. 2013, 78, 1306. http://dx.doi.org/10.1021/jo302585a

11. Xu, Y.; Li, B.; Li, W.; Zhao, J.; Sun, S.; Pang, Y. Chem. Commun. 2013, 49, 4764. http://dx.doi.org/10.1039/C3CC41994K

12. Shanmugaraju, S.; Joshi, S. A.; Mukherjee P. A. J. Mater. Chem., 2011, 21, 9130. http://dx.doi.org/10.1039/C1JM10406C 
13. Lin, S.-L.; Chan, L.-H.; Lee, R.-H.; Yen, M.-Y.; Kuo, W.-J.; Chen, C.-T.; Jeng, R.-J. $A d v$. Mater. 2008, 20, 3947. http://dx.doi.org/10.1002/adma.200801023

14. Kwak, J.; Lyu, Y.-Y.; Lee, H.; Choi, B.; Char, K.; Lee, C. J. Mater. Chem. 2012, 22, 6351. http://dx.doi.org/10.1039/C2JM15138C

15. Mortimer, R. J. Chem. Soc. Rev. 1997, 26, 147. http://dx.doi.org/10.1039/CS9972600147

16. Hagfelft, A.; Boschloo, G.; Kloo, L.; Pettersson, H. Chem. Rev. 2010, 110, 6595. http://dx.doi.org/10.1021/cr900356p

17. Sakong, C.; Kim H. J.; Kim, S. H.; Namgoong, J. W.; Park, J. H.; Ryu, J.-H.; Kim, B.; Ko, M. J.; Kim, J. P. New J. Chem. 2012, 36, 2025. http://dx.doi.org/10.1039/C2NJ40374A

18. Lin, Y.; Li, Y.; Zhan, X. Chem. Soc. Rev. 2012, 41, 4245. http://dx.doi.org/10.1039/c2cs15313k

19. Mishra, A.; Bäuerle, P. Angew. Chem. Int. Ed. 2012, 51, 2020. http://dx.doi.org/10.1002/anie.201102326

20. Kanaparthi, R. K.; Kandhdi, J.; Giribabu, L. Tetrahedron 2012, 68, 8383. http://dx.doi.org/10.1016/j.tet.2012.06.064

21. Liang, M.; Chen, J. Chem. Soc. Rev. 2013, 42, 3453. http://dx.doi.org/10.1039/c3cs35372a

22. Verbitskiy, E. V.; Cheprakova, E. M.; Subbotina, J.O.; Schepochkin, A.V.; Slepukhin, P. A.; Rusinov, G. L.; Charushin, V. N.; Chupakhin, O. N.; Makarova, N. I.; Metelitsa, A.V.; Minkin, V.I.; Dyes Pigments 2014, 100, 201.

http://dx.doi.org/10.1016/j.dyepig.2013.09.006

23. Verbitskiy, E. V.; Schepochkin, A.V.; Makarova, N. I.; Dorogan, I. V.; Metelitsa, A.V.; Minkin, V. I.; Kozyukhin, S. A.; Emets, V. V.; Grindberg, V. A.; Chupakhin, O. N.; Rusinov, G. L.; Charushin V.N. J. Fluoresc. 2015, 25, 763. http://dx.doi.org/10.1007/s10895-015-1565-6

24. Song, Y.; Di, C.; Xu, W.; Liu, Y.; Zhang, D.; Zhu, D. J. Mater. Chem. 2007, 17, 4483. http://dx.doi.org/10.1039/B708887F

25. Allard, S.; Forster, M.; Souharce, B.; Thiem, H.; Scherf, U. Angew. Chem. Int. Ed. 2008, 47, 4070 .

http://dx.doi.org/10.1002/anie.200701920

26. Wang, C.; Dong, H.; Hu, W.; Liu, Y.; Zhu, D. Chem. Rev. 2012, 112, 2208. http://dx.doi.org/10.1021/cr100380z

27. Zhao, Z.; Liu, J.; Lam, J. W. Y.; Chan, C. Y. K.; Qiu, H.; Tang, B. Z. Dyes Pigments 2011, $91,258$. http://dx.doi.org/10.1016/j.dyepig.2011.03.006

28. Prakash, K. S.; Nagarajan, R. Tetrahedron 2013, 69, 8269. http://dx.doi.org/10.1016/j.tet.2013.07.016 
29. Pati, P. B.; Zade, S. S. Tetrahedron Lett. 2014, 55, 5290.

http://dx.doi.org/10.1016/j.tetlet.2014.07.098

30. Peng, J.; Ye, K.; Sun, J.; Zhan, Y.; Jia, J.; Xue, P.; Zhang, G.; Zhang, Z.; Lu, R. Dyes Pigments 2015, 116, 36.

http://dx.doi.org/10.1016/j.dyepig.2015.01.009

31. Zhang, Y.; Pan, J.; Zhang, C.; Wang, H.; Zhang, G.; Kong, L.; Tian, Y.; Jiaxiang Yang, J. Dyes Pigments 2015, 123, 257.

http://dx.doi.org/10.1016/j.dyepig.2015.08.013

32. Liu, T.; Ding, L.; He, G.; Yang, Y.; Wang, W.; Fang, Y. ACS Appl. Mater. Interfaces 2011, 3, 1245 .

http://dx.doi.org/10.1021/am2000592

33. Liu, T.; Ding, L.; Zhao, K.; Wang, W.; Fang, Y. J. Mater. Chem. 2012, 22, 1069. http://dx.doi.org/10.1039/C1JM14022A

34. Liu, T.; Zhao, K.; Liu, K.; Ding, L.; Yin, S.; Fang, Y. J. Hazard. Mater. 2013, 246-247, 52. http://dx.doi.org/10.1016/j.jhazmat.2012.11.010

35. Achelle, S.; Plé, N. Curr. Org. Synth. 2012, 9, 163.

36. Achelle, S.; Baudequin, C. Targets Heterocycl. Syst. 2013, 17, 1.

37. Itami, K.; Yamazaki, D.; Yoshida, J. J. Am. Chem. Soc. 2004,126,15396. http://dx.doi.org/10.1021/ja044923w

38. Bagley, M. C.; Lin, Z.; Pope, S. J. A. Tetrahedron Lett. 2009, 50, 6818. http://dx.doi.org/10.1016/j.tetlet.2009.09.116

39. Castet, F.; Pic, A.; Champagne, B. Dyes Pigments 2014, 110, 256. http://dx.doi.org/10.1016/j.dyepig.2014.03.021

40. Denneval, C.; Achelle, S.; Baudequin, C.; Robin-le Guen, F. Dyes Pigments 2014, 110, 49. http://dx.doi.org/10.1016/j.dyepig.2014.05.030

41. Achelle, S.; Rodríguez-López, J.; Bureš, F.; Robin-le Guen, F. Dyes Pigments 2015, 121, 305.

http://dx.doi.org/10.1016/j.dyepig.2015.05.026

42. Achelle, S.; Kahlal, S.; Barsella, A.; Saillard, J.-I.; Che, X.; Vallet, J.; Bureš, F.; Bertrand Caro, B.; Robin-le Guen, F. Dyes Pigments 2015, 113, 562. http://dx.doi.org/10.1016/j.dyepig.2014.09.028

43. Cvejn, D.; Achelle, S.; Pytela, O.; Malval, J.-P.; Spangenberg, A.; Cabon, N.; Bureš, F.; Robin-le Guen, F. Dyes Pigments 2016, 124, 101. http://dx.doi.org/10.1016/j.dyepig.2015.09.012

44. Verbitskiy, E. V.; Cheprakova, E. M.; Zhilina, E. F.; Kodess, M. I.; Ezhikova, M. A.; Pervova, M.G.; Slepukhin, P. A.; Subbotina, J.O.; Schepochkin, A.V.; Rusinov, G. L.; Chupakhin, O. N.; Charushin, V. N. Tetrahedron 2013, 69, 5164. http://dx.doi.org/10.1016/j.tet.2013.04.062 
45. Verbitskiy, E. V.; Cheprakova, E. M.; Slepukhin, P.A.; Kodess, M. I.; Ezhikova, M. A.; Pervova, M. G.; Rusinov, G. L.; Chupakhin, O. N.; Charushin V. N. Tetrahedron 2012, 68, 5445.

http://dx.doi.org/10.1016/j.tet.2012.04.095

46. Verbitskiy, E. V.; Rusinov, G. L.; Charushin, V. N.; Chupakhin, O. N.; Cheprakova, E. M.; Slepukhin, P. A.; Pervova, M. G.; Ezhikova, M. A.; Kodess M. I. Eur. J. Org. Chem. 2012, 6612.

http://dx.doi.org/10.1002/ejoc.201201035

47. Verbitskiy, E. V.; Slepukhin, P. A.; Valova, M. S.; Cheprakova, E. M.; Schepochkin, A. V.; Rusinov, G. L.; Charushin V. N. Eur. J. Org. Chem. 2014, 36, 8133. http://dx.doi.org/10.1002/ejoc.201403212

48. Barltrop, J.A.; Coyle, J. D. Excited States in Organic Chemistry. London, New York: Wiley; 1975. p. 376.

49. Liu, T.; Zhao, K.; Liu, K.; Ding, L.; Yin, S.; Fang, Y. J. Hazard. Mater. 2013, 246-247, 52. http://dx.doi.org/10.1016/j.jhazmat.2012.11.010

50. Brouwer, A. M. Pure Appl. Chem. 2011, 83, 2213. http://dx.doi.org/10.1351/PAC-REP-10-09-31 